\title{
Primary Stenting for Recurrent Stenosis Following Carotid Endarterectomy
}

\author{
Miguel Bussière, David M. Pelz, Stephen P. Lownie
}

\begin{abstract}
Background: Carotid angioplasty and stenting is an accepted alternative treatment for severe restenosis following carotid endarterectomy. Balloons may not be required to effectively treat these lesions, given their altered histopathology compared to primary atherosclerotic plaque and tendency to be less calcified. Primary stenting using self-expanding stents alone may, therefore, be a safe and effective treatment for restenosis post-carotid endarterectomy. Methods: We review our experience in the treatment of 12 patients with symptomatic severe restenosis following carotid endarterectomy with primary stent placement alone. Results: Self-expanding stent placement alone reduced the mean internal carotid artery stenosis from $85 \%$ to $29 \%$. Average peak systolic velocity determined at the time of ultrasonography decreased from $480 \mathrm{~cm} / \mathrm{s}$ at initial presentation to $154 \mathrm{~cm} / \mathrm{s}$ post-stent deployment and further decreased to 104 $\mathrm{cm} / \mathrm{s}$ at one year follow-up. The stented arteries remained widely patent with no evidence of restenosis. A single peri-procedural ipsilateral transient ischemic event occurred. There were no cerebral or cardiac ischemic events recorded at one year of follow-up. Conclusions: In this series, primary stent placement without use of angioplasty balloons was a safe and effective treatment for symptomatic restenosis following carotid endarterectomy.
\end{abstract}

RÉSUMÉ: La pose d'emblée d'une endoprothèse dans la récidive d'une sténose après une endartérectomie carotidienne. Contexte : L'angioplastie carotidienne et la pose d'une endoprothèse est une solution de rechange acceptée pour le traitement d'une resténose sévère après une endartérectomie carotidienne. Le traitement de ces lésions ne requière pas nécessairement l'utilisation du ballon parce que leur histopathologie est modifiée par rapport à la plaque athéroscléreuse primaire et qu'elles sont en général moins calcifiées. La pose d'emblée d'une endoprothèse autoexpansive sans autre intervention pourrait donc être un traitement sûr et efficace pour le traitement de la resténose après une endartérectomie carotidienne. Méthodes : Nous revoyons notre expérience de ce traitement chez douze patients porteurs de resténoses sévères symptomatiques après une endartérectomie carotidienne. Résultats : La pose d'une endoprothèse autoexpansive sans autre intervention a diminué la sténose moyenne de la carotide interne de $85 \%$ à $29 \%$. Le pic moyen de vélocité systolique maximale au moment de l'échographie a diminué de $480 \mathrm{~cm} / \mathrm{s}$ avant l'intervention à $154 \mathrm{~cm} / \mathrm{s}$ après la mise en place de l'endoprothèse et à $104 \mathrm{~cm} / \mathrm{s}$ lors d'une évaluation faite un an plus tard. Les artères porteuses d'endoprothèses sont demeurées très perméables, sans signe de resténose. Un seul événement ischémique transitoire homolatéral péri-opératoire a été noté. Il n’y a eu aucun événement ischémique cérébral ou cardiaque rapporté au moment du suivi fait 1 an plus tard. Conclusions : Dans cette série d'observations, la mise en place d'une endoprothèse d'emblée, sans avoir recours à une angioplastie par ballon, s'est avérée sûre et efficace pour traiter la resténose symptomatique après une endartérectomie carotidienne.

Can. J. Neurol. Sci. 2009; 36: 332-335

The reported incidence of restenosis following carotid endarterectomy (CEA) varies widely in the literature due to differences in the definition of restenosis, method of detection and length of follow-up. Lattimer and Burnand ${ }^{1}$ found a range of 1 to $37 \%$ in a review of 55 studies $^{1}$. Frericks et al ${ }^{2}$ found that the risk of restenosis is not constant but diminishes with time ${ }^{2}$. The annual rate of restenosis gradually diminished from $10 \%$ in the first year to $1 \%$ over the next three years following surgery ${ }^{2}$. Symptomatic restenosis is less frequent occurring in $0.1-8 \%$ of patients with restenosis ${ }^{1-3}$.

Although several published series document successful reoperation for post-CEA restenosis ${ }^{4-6}$, redo surgery is technically more challenging and may carry an increased risk of peri-operative complications such as cranial nerve injury and wound hematoma ${ }^{7,8}$. Carotid angioplasty and stenting has thus become an acceptable alternative therapy for post- endarterectomy restenosis ${ }^{9-12}$. There have been several recent reports of self-expanding stents (SES) used alone, without angioplasty or embolic protection devices, to successfully treat carotid stenoses $^{13-17}$. The goal of the current study was to review our experience in the treatment of post-CEA restenosis using primary stent placement alone.

From the Divisions of Neurology and Neuroradiology (MB), The Ottawa Hospital, Ottawa; Department of Medical Imaging (DMP, SPL), Department of Clinical Neurological Sciences (SPL), London Health Sciences Centre, London, Ontario. Received September 5, 2008. Final Revisions Submitted December 18, 2008 Correspondence to: Miguel Bussière, Neurology and Interventional Neuroradiology, C2, Room 2174, Civic Campus, The Ottawa Hospital, 1053 Carling Avenue, Ottawa, Ontario, K1Y 4E9, Canada. 


\section{METHODS}

Twelve symptomatic patients with severe restenosis postCEA were treated by primary stent placement at the London Health Sciences Centre. One additional patient was excluded from the analysis because pre-dilation of the stenosis with a balloon was necessary to allow a stent to be physically positioned across the stenosis. Data from this cohort was prospectively collected into a registry and retrospectively analyzed. Eight patients in this cohort were included in a prior report $^{15}$.

Details of the stenting technique have been previously reported $^{14,15}$. Briefly, the goal at procedure onset was to deploy a SES alone without use of angioplasty balloons or embolic protection device. Patients were pre-treated with clopidogrel and acetylsalicylic acid for four to five days prior to the stenting procedure. Systemic heparinization was maintained throughout the procedure.

After positioning a guiding catheter in the common carotid artery, the stenosis was crossed with a micro-guidewire. An 8 $\mathrm{mm}$ diameter and $40 \mathrm{~mm}$ length SES was centered across the stenosis. A Cordis Precise stent (Cordis, Miami, Fla) was used for 11 patients and an early generation Wallstent (Boston Scientific, Natick, Mass) for one patient. Balloon post-dilatation was not performed and there was no minimum lumen diameter required at the end of the procedure. Heparinization was allowed to gradually wear off. Acetylsalicylic acid and clopidogrel were maintained for four to six weeks at which time one agent was discontinued.

At the time of angiography, the degree of stenosis before and immediately post-stenting were recorded. Patients were assessed at regular intervals (24 hours, 1-2 months, 6 months, 1 year) over the following year in clinic and with Duplex ultrasonography. Restenosis post-stenting was defined in two ways: [1] A mean peak systolic velocity (PSV) of $>220 \mathrm{~cm} / \mathrm{s}$ and ICA/CCA velocity ratio of $>2.7^{18}$, which correlates with a stenosis of $>50 \%$ in stented carotid arteries [2] Consecutive measurements demonstrating a trend towards increasing velocities. This second criterion was chosen because SES continue to gradually expand over the first year after placement ${ }^{14,15}$. Consequently, although peak systolic velocities immediately post-stenting may remain elevated in some patients, subsequent velocity measurements fall as the stent gradually expands ${ }^{14,15}$.

\section{RESULTS}

Twelve symptomatic patients with severe $(>70 \%)$ restenosis post-CEA were treated by primary stenting. The patients were on average 70 years-of-age (range 52-82) and 7 of 12 were female. All patients had significant vascular risk factors (Table) including hypertension (100\%), hyperlipidemia (100\%), diabetes $(25 \%)$, coronary artery disease $(50 \%)$ and a current or past history of smoking $(58 \%)$. The interval between CEA and clinical presentation was $<2$ years in $25 \%$, between $2-5$ years in $25 \%$ and $>5$ years in $50 \%$ of patients. The presenting ipsilateral ischemic event was a minor stroke $(50 \%)$, transient ischemic attack $(25 \%)$ or amaurosis fugax $(25 \%)$.

Restenotic lesions were mostly smooth with ulceration observed in only two patients and significant calcification in only three patients (Table). With self expanding stent placement

\section{Table: Patient characteristics}

\begin{tabular}{|c|c|c|}
\hline Patient characteristics & $\mathrm{n}$ & \\
\hline Age, mean (range) & $70(52-82)$ & \\
\hline Female & 7 & $58 \%$ \\
\hline \multicolumn{3}{|l|}{ Vascular risk factors } \\
\hline Diabetes & 3 & $25 \%$ \\
\hline Hyperlipidemia & 12 & $100 \%$ \\
\hline Hypertension & 12 & $100 \%$ \\
\hline Coronary artery disease & 6 & $50 \%$ \\
\hline Smoking & 7 & $58 \%$ \\
\hline \multicolumn{3}{|c|}{ Interval from CEA to presentation } \\
\hline$<2$ years & 3 & $25 \%$ \\
\hline $2-5$ years & 3 & $25 \%$ \\
\hline$>5$ years & 6 & $50 \%$ \\
\hline \multicolumn{3}{|l|}{ Presenting event } \\
\hline Amaurosis & 5 & $42 \%$ \\
\hline TIA & 4 & $33 \%$ \\
\hline Stroke & 3 & $25 \%$ \\
\hline \multicolumn{3}{|l|}{ Angiographic factors } \\
\hline Left ICA stenosis & 6 & $50 \%$ \\
\hline Percent stenosis (range) & $85(73-95)$ & \\
\hline Ulceration & 2 & $17 \%$ \\
\hline \multicolumn{3}{|c|}{ Circumferential calcification } \\
\hline $0-25 \%$ & 9 & $75 \%$ \\
\hline $25-50 \%$ & 1 & $9 \%$ \\
\hline $50-75 \%$ & 2 & $17 \%$ \\
\hline $75-100 \%$ & 0 & \\
\hline
\end{tabular}

TIA=transient ischemic attack; ICA=internal carotid stenois

alone, mean internal carotid artery stenosis was reduced from $85 \%$ (median $83 \%$, range $73-95 \%$ ) to $29 \%$ (median $30 \%$, range $0-70 \%)$. Average peak systolic velocity decreased from $480 \mathrm{~cm} / \mathrm{s}$ (median 507, range $209-672 \mathrm{~cm} / \mathrm{s}$ ) at initial presentation to 154 $\mathrm{cm} / \mathrm{s}$ (median 143, range $70-262 \mathrm{~cm} / \mathrm{s}$ ) post-stent deployment. At one year follow-up, mean peak systolic velocity had further decreased to $104 \mathrm{~cm} / \mathrm{s}$ (median 110, range 40-153 cm/s) (Figure). Similarly, the internal carotid artery to common carotid artery velocity ratio decreased from 9.8 (median 9.1, range 2.7-21.1) to 1.9 (median 1.7, range 0.9-3.9) post-stenting and remained stable over the following year.

During the stenting procedure, a single patient experienced an ipsilateral transient ischemic attack of less than 15 minutes duration. There were no further cerebral or cardiac ischemic events in the peri-procedural period (0-30 days) and no deaths. At one year of follow-up, no transient ischemic events, strokes or deaths occurred. The stented arteries remained widely patent with no evidence of restenosis. One patient had an elevated ICA/CCA velocity ratio of 3.9 at one year, though the peak systolic velocity was $109 \mathrm{~cm} / \mathrm{s}$ and both values had been falling over serial recordings. 


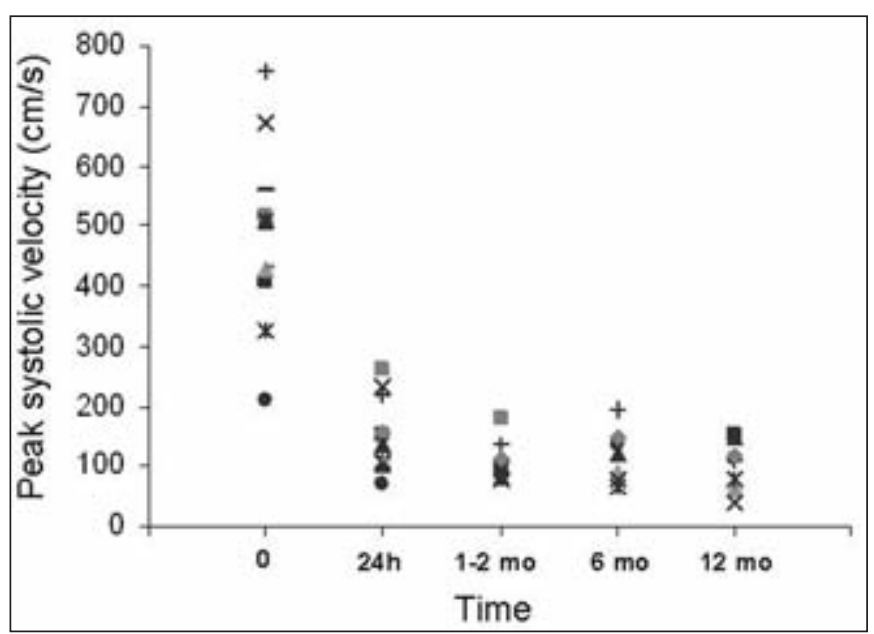

Figure: Decreasing velocities over the first year post-stenting. Serial Duplex ultrasonography peak systolic velocity measurements over one year of follow-up. Each point represents the measurements from a single patient. $\mathrm{cm} / \mathrm{s}$, centimetres per second; $h$, hours; mo, months

\section{Discussion}

The histopathology of post-CEA restenosis varies based on the time interval of recurrence. Late restenosis, occurring greater than five years after surgery, represents recurrent atherosclerosis and resembles primary plaque with increased macrophage infiltration, calcification and lipid core ${ }^{19}$. Early recurrence, occurring within two years of surgery, is the result of neointimal hyperplasia with increased accumulation of smooth muscle cells and less inflammatory infiltration, calcification and lipid accumulation $^{19}$. Similar to symptomatic primary plaque ${ }^{20-22}$, restenotic lesions that give rise to thromboembolic events are associated with a larger lipid core and inflammatory infiltrate ${ }^{19}$.

Primary placement of a self-expanding stent was a safe and effective treatment for symptomatic post-CEA restenosis in this series. Patients with early and late recurrence were successfully treated with follow-up to one year. Heavy concentric plaque calcification and very severe stenosis are associated with decreased efficacy of primary stenting for carotid stenosis ${ }^{15}$. Restenotic lesions occurring after endarterectomy tend to be less calcified $^{19}$. This is particularly true when recurrence occurs early within two years of surgery. Three-quarters of the patients in our cohort had little or no plaque calcification. This difference between primary and restenotic plaque may at least partially explain the success of this technique in treating patients with restenosis following endarterectomy.

Several limitations of this study are acknowledged. The number of patients treated is small and follow-up relatively short. Longer follow-up will be required to determine whether the technique will have a long lasting benefit and whether patients will remain free of restenosis. All patients treated in this cohort were symptomatic. The efficacy of primary stenting for asymptomatic restenoses is unknown. Asymptomatic carotid stenosis has been treated successfully with self expanding stents alone in other series, however ${ }^{16,17}$. Lastly, there are several selfexpanding stent systems available for the treatment of carotid stenosis which vary in the profile of the leading edge, stent cell design, flexibility, conformability and chronic outward force. Variability in stent chronic outward force, in particular, may affect the ability of a stent to gradually expand and dilate a stenosed artery. The efficacy of other stent systems using this technique cannot be commented upon since all but one patient in this cohort were treated with the same stent.

In this series, primary stent placement without use of angioplasty balloons or embolic protection devices was a safe and effective treatment for symptomatic restenotic lesions following carotid endarterectomy.

\section{REFERENCES}

1. Lattimer CR, Burnand KG. Recurrent carotid stenosis after carotid endarterectomy. Br J Surg. 1997;84:1206-19.

2. Frericks H, Kievit J, van Baalen JM, van Bockel JH. Carotid recurrent stenosis and risk of ipsilateral stroke: a systematic review of the literature. Stroke. 1998;29:244-50.

3. Carballo RE, Towne JB, Seabrook GR, Freischlag JA, Cambria RA. An outcome analysis of carotid endarterectomy: the incidence and natural history of recurrent stenosis. J Vasc Surg. 1996:23:749-54.

4. Treiman GS, Jenkins JM, Edwards WH Sr, Barlow W, Edwards WH Jr, Martin RS 3rd, et al. The evolving surgical management of recurrent carotid stenosis. J Vasc Surg. 1992;16:354-62.

5. Mansour MA, Kang SS, Baker WH, Watson WC, Littooy FN, Labropoulos $\mathrm{N}$, et al. Carotid endarterectomy for recurrent stenosis. J Vasc Surg. 1997;25:877-83.

6. Hill BB, Olcott C IV, Dalman RL, Harris EJ, Jr, Zarins CK. Reoperation for carotid stenosis is as safe as primary carotid endarterectomy. J Vasc Surg. 1999;30:26-35.

7. Hobson RW II, Goldstein JE, Jamil Z, Lee BC, Padberg FI Jr, Hanna AK, et al. Carotid restenosis: operative and endovascular management. J Vasc Surg. 1999;29:228-35.

8. Abu-Rahma AF, Jennings TG, Wulu JT, Tarahji L, Robinson PA. Redo carotid endarterectomy versus primary carotid endarterectomy. Stroke. 2001;32:2787-92.

9. Veith FJ, Amor M, Ohki T, Beebe HG, Bell PR, Bolia A, et al. Current status of carotid bifurcation angioplasty and stenting based on a consensus of opinion leaders. J Vasc Surg. 2001;33 Suppl 2:S111-6.

10. Vitek JJ, Roubin GS, New G, Al-Mubarek N, Iyer SS. Carotid angioplasty with stenting in post-carotid endarterectomy restenosis. J Invasive Cardiol. 2001;13:123-5.

11. Lal BK. Recurrent carotid stenosis after CEA and CAS: diagnosis and management. Semin Vasc Surg. 2006;20:259-66.

12. Sadideen H, Taylor PR, Padayachee TS. Restenosis after carotid endarterectomy. Int J Clin Pract. 2006;60:1625-30.

13. Men S, Lownie SP, Pelz DM. Carotid stenting without angioplasty. Can J Neurol Sci. 2002;29:175-9.

14. Lownie SP, Pelz DM, Lee DH, Men S, Gulka I, Kalapos P. Efficacy of treatment of severe carotid bifurcation stenosis by using selfexpanding stents without deliberate use of angioplasty balloons. AJNR Am J Neuroradiol. 2005;26:1241-8.

15. Bussière M, Pelz DM, Kalapos P, Lee D, Gulka I, Leung A, et al. Results using a self-expanding stent alone in the treatment of severe symptomatic carotid bifurcation stenosis. J Neurosurg. 2008;109:454-60.

16. Maynar M, Baldi S, Rostagno R, Zander T, Rabellino M, Llorens $\mathrm{R}$, et al. Carotid stenting without use of balloon angioplasty and distal protection devices: preliminary experience in 100 cases. AJNR Am J Neuroradiol. 2007;28:1378-83.

17. Leonardi M, Dall'Olio M, Raffi L, Cenni P, Simonetti L, Marasco $\mathrm{R}$, et al. Carotid stenting without angioplasty and without protection. The advantages of a less invasive procedure. Int Neurorad. 2008;14:153-64. 
18. Lal BK, Hobson RW 2nd, Tofighi B, Kapadia I, Cuadra S, Jamil Z. Duplex ultrasound velocity criteria for the stented carotid artery. J Vasc Surg. 2008;47:63-73.

19. Hellings WE, Moll FL, de Vries JPPM, de Bruin P, de Kleijn DPV, Pasterkamp G. Histological characterization of restenotic carotid plaques in relation to recurrence interval and clinical presentation. A cohort study. Stroke. 2008;39:1029-32.

20. Spagnoli LG, Mauriello A, Sangiorgi G, Fratoni S, Bonanno E, Schwartz RS, et al. Extracranial thrombotically active carotid plaque as a risk factor for ischemic stroke. JAMA. 2004;292: $1845-52$.
21. Verhoeven B, Hellings WE, Moll FL, de Vries JP, de Kleijn DP, Busser E, et al. Carotid atherosclerotic plaques in patients with transient ischemic attacks and stroke have unstable characteristics compared with plaques in asymptomatic and amaurosis fugax patients. J Vasc Surg. 2005;42:1075-81.

22. Redgrave JN, Lovett JK, Gallagher PJ, Rothwell PM. Histological assessment of 526 symptomatic carotid plaques in relation to the nature and timing of ischemic symptoms: the Oxford plaque study. Circulation. 2006;113:2320-8. 